\title{
Normative regulations and the use of language in describing po- litical events: an analysis of the pragmatic use of language on newspapers
}

Regulaciones normativas y uso del lenguaje en la descripción de eventos políticos: Un análisis del uso pragmático del lenguaje en los periódicos

\author{
José Francisco Valencia \\ Lorena Gil de Montes \\ Garbiñe Ortiz \\ Maider Larrañaga \\ Universidad del País Vasco/ Euskal Herriko Unibertsitatea
}

Abstract

The Linguistic Intergroup Bias is defined as the tendency to describe positive ingroup and negative outgroup behaviors in more abstract linguistic categories than negative ingroup and positive outgroup behavior (Fiedler et al, 2003). Basing itself on Moscovici's idea that "something" is beyond the text, (1994, p. 163), three studies analyze the use of language in newspaper editorials. Editorials were selected from different newspapers describing different political relevant events: the killing of politicians, the truce of ETA, and the banning of a Basque newspaper. Verbs and adjectives were coded according to the Linguistic Category Model (Semin \& Fiedler 1988). According to the LCM, results show that newspapers transmit their point of view by describing differently member aggressors from the ingroup and from the outgroup (Study 1 and 3). Results also show that this effect lasts even when the explicit conflictive situation is no longer going on (Study 2). In sum, results showed that a subtle language use expressing dispositional driven regulations is used depending on the position taken by the media. Finally, the pertinence of the Theory of Social Representations to explain the use of different normative pragmatic regulations is discussed to understand this pragmatic use of language that is so consistent in the mass media.

Keywords:Communication; Linguistic abstraction; Pragmatic logics; Language use; Social representations

\section{Resumen}

El Sesgo Lingüístico Intergrupal se define como la tendencia a describir comportamientos positivos del endogrupo y negativos del exogrupo en categorías linguísticas más abstractas que el comportamiento negativo en el endogrupo y el positivo en el exogrupo (Fiedler, Bluemke, Friese \& Hofmann, 2003). Basándose en la idea de Moscovici que "algo" está detrás del texto (1994, p. 163), se presentan tres estudios que analizan el uso del lenguaje en editoriales de periódicos. Se seleccionaron editoriales de periódicos diversos en los que se describen diferentes eventos políticos relevantes: asesinato de políticos, la tregua de ETA y la censura de un periódico vasco. Los verbos y los adjetivos fueron codificados de acuerdo con el Modelo de Categorías Linguísticas (Semin \& Fiedler 1988). De acuerdo con el MCL, los resultados muestran que los periódicos transmiten su perspectiva al describir de mane- 
ra diferente a los agresores de los miembros del endogrupo y del exogrupo (Estudios 1 y 3). Los resultados también muestran que dicho efecto persiste incluso cuando la situación conflictiva ya no está presente (Estudio 2). En suma, los resultados muestran que, dependiendo de la perspectiva de la posición tomada por el medio, se produce un uso sutil del lenguaje, el cual expresa regulaciones dirigidas por disposiciones. Finalmente, se discute la pertinencia de la Teoría de las Representaciones Sociales para explicar el uso de las diferentes regulaciones normativas, para entender este uso pragmático del lenguaje, tan consistente en los medios de comunicación.

Palabras clave:Comunicación; Abstracción lingüística; Lógicas pragmáticas; Uso del lenguaje; Representaciones sociales

\section{Introduction}

Fifteen years ago, Moscovici claimed that 'something' was beyond the text when he argued that 'the whole communicative value of the phrase is not condensed in the meaning alone' (1994, p. 163). According to the author, the previous study of Social Representations (SR) has had an important limitation: 'throughout the studies on the way representations are shaped and diffused in ordinary communication I have privileged questions of meaning' (1994, p. 164). This limitation stems from two sources: a) from privileging issues of form or mental architecture; b) from the interaction between psychological content and linguistic content, especially due to the notion of anchoring, which was defined as guided by the analogy between thought and language.

Several attempts have recently come into examining the relation between language use and social representations (Grice 1989, Van Dijk 1998, Wagner, Kronberger \& Seifert, 2002). There is, however, another recent attempt that might help us overcome the limitation derived from the semantic communication and support the pragmatic dimension: The Linguistic Intergroup Bias (LIB) is based on the analytical frame of symbolic communication -known as the Tool-and-Tool-UseModel- and on the classification of linguistic terms across the Linguistic Category Model (LCM) (Semin \& Fiedler, 1988; 1991).

\section{Language in the media}

The issue of accuracy versus manipulation of the language used in the media has been the subject of strong debates in the social sciences. Disentangling this Hegelian Mystery has occupied theoreticians and social thinkers along the 20th century. George Orwell's impressive essay Nineteen eighty-four on the re- lationship between 'duckspeak' and 'doublethink' in his 'newspeak' underlined fear and suspicion of manipulation. A current viewpoint is Herman and Chomsky's Manufacturing Consent which holds that the media serves the mobilisation of support for the special interests that rule the State and private activity, and that the propagandistic role of the American press is by no means different from the role Pravda played in the Soviet Union. However, this functionalist perspective makes many of the most dramatic changes in the past half century inexplicable. For instance, De Mateo's (1989) sketch of the newspaper industry in Spain emphasizes the different roles played by the press during Franco's regime, the transition to democracy and the full restoration of democracy. While newspapers made ideological purity their first priority during Franco's Regime, from the transition on, however, the same profit-making press provided chances for freedom of speech. In the same way, Zaller (1998) explained how public opinion has been entirely unaffected by the news of the White House's scandal concerning Clinton and Lewinsky. Even if it is true that both perspectives are working together (accuracy vs.. manipulation), it is not untrue that a third line of research examines news as a form of culture that often unconsciously incorporates general belief systems, assumptions, and values into news writing (Schudson, 2002).

The polarization between manipulation vs.. accuracy has left aside the analysis of less obvious strategies of language use. One of the emerging strategies that has recently been implemented in the area of language use in the media is the LIB (Maass, Salvi, Arcuri, \& Semin, 1989). The linguistic intergroup bias is a phenomenon that emerges when abstraction used in linguistic terms is considered in inter- 
group settings. Specifically, it predicts positive behaviours performed by ingroup members that tend to be described in a more abstract fashion that ingroup negative behaviours. In this way, positive behaviours are given stability in language whereas negative behaviours are communicated as something unstable and not likely to be repeated. On the contrary, when communicating behaviours about outgroup members, negative behaviours are given stability by using an abstract language, whereas positive behaviours are typically described more concretely. Two alternative mechanisms have been held responsible for emergence of the LIB; namely, cognitive and motivational social psychological processes. As far as intergroup events in the media ascribing to different ideologies are concerned, social identity protection processes are expected to explain events imposing intergroup threat. In their seminal paper, Maass, Corvino and Arcuri (1994) provided empirical evidence for the occurrence of LIB in the mass media across three studies: the report of a soccer match between two competing teams in the first study, the description of an antisemitic aggression in the second one, and a report about the Gulf war in the third one. These authors found that journalists used a more concrete language when the desirable behaviours and successes of the opposite soccer team were described than when the successes of their own team were described. In the case of the anti-Semitic aggression, Jewish and nonJewish newspapers described the aggressor in the same negative terms, but non-Jewish journalists used a more concrete language than Jewish journalists did. Finally, in the case of the Gulf war, the more negative the sentences about Iraq during the Gulf war, the more abstract they were. These three studies provided empirical evidence for the LIB in the mass media.

\section{The Linguistic Category Model and language use}

The recent interplay between linguistics and social psychology (Valencia, Gil de Montes \& Ortiz, 2007) has provided social psychology with a privileged perspective for the analysis of the relation between language use and thought in a pragmatic way. In other words, this implies taking language as a pragmatic tool directed to the achievement of goals (Krauss and Chiu, 1998). Accordingly, Semin
(1998), grounded on Mead's, Vygotsky's, Berger's and Luckmann's views, has proposed to consider language in a pragmatic way: as a tool -with determined and finite propertiesand language used as a tool-use -with undetermined productions-. The properties of the tools can only be manifested in pragmatic contexts, that means 'in the hands' of skilled or capable tool users.

According to the LCM (Maass 1999; Semin \& Fiedler, 1991), verbs and adjectives are used as tools in the service of constructing a speech act in a communicative context. In such a message construction process, verbs are employed in the pursuit of attaining particular communicative goals or communicating specific intentions. Thus, the goals that individuals and groups establish for themselves are expressions given in the form of an utterance or a symbolic communication. This symbolic communication consists of a cooperative task (Grice, 1989) with the strategic choice of verbs by emphasizing specific affordances of the tools to come to the fore, i.e. to appear on the media by using distinct linguistic devices.

The application of the LCM (Semin \& Fiedler, 1991) allows identifying in language the socalled LIB. This process posits that there is a systematic bias in descriptions of intergroup relationships, which contributes to the maintenance of existing stereotypical beliefs. In particular, positive behaviours tend to be communicated in abstract terms when performed by members of ingroup members (i.e. A is amiable) while the same behaviour performed by members of the outgroup is likely to be communicated in more concrete terms (i.e., A makes a bet). In contrast, negative behaviours are usually described in concrete terms when performed by ingroup members (i.e., A hurts B) and in abstract terms when performed by a member of an outgroup ( $\mathrm{A}$ is aggressive). In sum, Maass \& Arcuri (1992) claimed that in intergroup situations, a bias in the use of language is likely to occur, which contributes to the maintenance of established cognitive biases.

The LCM (Semin \& Fiedler, 1988) distinguishes four linguistic categories in a continuum of diverse abstraction level. The same behaviour, at the most concrete level, may be described in terms of Descriptive Action Verbs (DAV, A hits $B)$, to the extent that it offers an objective de- 
scription of a single, observable event, defined by at least one physically invariant feature. At a slightly more abstract level, the same behaviour may be described in terms of Interpretive Action Verbs (IAV, A hurts B); it is described as a class of behaviours that directly refer to a specific behaviour in a specific situation. In contrast to DAV, IAVs. are no longer bound to physically invariant features though they preserve the reference to a single behavioural episode. At a more abstract level, the same behaviour may be described in terms of State Verbs (SV, A hates B); they are described as psychologically enduring states, they have neither direct reference to a specific behavioural episode nor to specific situations, though they refer to a specific object. At the most abstract level, the same behaviour may be described in terms of Adjectives (ADJ, A is Aggressive). They describe people's highly abstract dispositions, which provide generalisations across specific behavioural events, situations, behaviours, and objects.

\section{Language use and normative pragmatic reg- ulations}

According to Doise (1990), it is normative regulations carried out by the social metasystem on the cognitive system that constitute the very object of the study of social representations, to the extent that their relations to specific positions in a network of social relations are explicit. According to these positions, the demands of the meta-system will vary. In other words, the cognitive operations that have traditionally been examined from a social cognitive viewpoint are guided by different social regulations (Moscovici, 1986; 1994); concretely, by the normative regulations that control, verify and rule such cognitive operations.

This relationship between the organising principles of social regulations and cognitive operations, however, is not new in social psychology (Beauvois, Gilibert, Pansu, \& Abdelaoui, 1998; Cates \& Messick, 1996; Doise, 1993; Flament, 1999; Ichheiser, 1949; Jellison \& Green, 1981: -see also, Doise and Staerklé, 2001-). The use of linguistic abstraction is directed by "those kind of pragmatic regulations" aimed at detaching the actors from the context (or fixing the actor to the context) in order to foster inferences to the "addressee" of communication. Thus, the classification criteria of linguistic abstraction based on the
LCM (Semin, 1998, 2000), allows describing the same event at different levels of linguistic abstraction.

In the literature about linguistic abstraction, two main organising principles of the description of behaviour have been found (Semin \& Fiedler, 1989; Valencia Gil de Montes, \& Ortiz, 2007; Wigboldus, Semin, \& Spears, 2000): Dispositionality and Causal Intentionality. The theoretical rationale for explaining these principles comes from the literature about cognitive attribution. This theoretical rationale also had to do with the original explanation of the behavioural style in minority influenced literature (Moscovici, 1976).

The first dimension, high dispositionality (the use of abstract terms as ADJ is opposed to a more concrete terms as DAV), emphasizes high temporal stability, less situation dependence, and higher globality thus providing information about the subject's personality, implying voluntary control and leading to inferences about more internal causes dispositions- as being responsible for the action (Fiedler, Semin, \& Finkenauer, 1993; Schmid \& Fiedler, 1998; Schmid, Fiedler, Englich, Ehrenberg, \& Semin, 1996). High dispositionality emphasizes the stable and global nature of the behaviour performed by a target person, separating the actor from the context. In other words, the higher the dispositionality and the higher the consistency (temporal stability), the lower the distinctiveness (less situational dependency) and the lower the consensus (high subject informativeness and low verifiability), to use Kelley's (1973) dimensions.

The second dimension, high intentional causality (verbs like SV as opposed to IAV), emphasizes that the cause of an emotional state is more likely to be found in the stimulus than in the person or subject-sentence. This "psychological causality implicit in language" (Brown \& Fish 1983, p. 242) leads to the consideration of a discourse grammar, linking interpersonal actions and antecedents as well as subsequent emotions (Semin \& Fiedler, 1992; Semin \& Marsman, 1994). Therefore, the use of IAV (subject-object sentence) leads to inferences relating to personal responsibility and voluntary control of premeditated behaviours as opposed to reactions driven by the use of SV (stimulus-experience sentence). According to Brown and Fish, (1983, see also 
Rudolph \& Forsteling, 1997) high causal intentionality gives room to high voluntary control and intentionality about the behaviour of the subject because of the causal logic of agentpatient, while low causal intentionality, however, gives room to high voluntary control and intentionality about the behaviour of the stimulus because of the causal logic of stimulus-subject (Weiner, 1986). Accordingly, characterizing specific behaviours in terms of abstract linguistic categories attenuates the perceived causal contribution of situational factors and enhances the perceived contribution of dispositional factors (Semin \& Fiedler, 1988).

Thus, while the use of high dispositionality induces inferences detaching the person from the context, causal intentionality induces inferences about the controllability of the behaviour, leading to a denial of responsibility to the actor in the case of SV and to addressing responsibility to the actor in the case of the use of IAV.

The current hypothesis was that different levels of the linguistic abstraction -the different normative regulations- used by newspapers would appear when describing different political events depending on the position they take on the political conflict.

In particular, in our first study we hypothesised that nationalist newspapers describe the aggressor of the nationalist politician in more abstract terms than non-nationalist newspapers, while non-nationalist newspapers would describe the aggressor of the non-nationalist politician in more abstract terms than nationalist newspapers. Specifically an interaction among ideological viewpoints of the newspaper (nationalist vs.. non-nationalist), sentencesubject (aggressor vs.. victim) and the abstraction level (abstract-concrete) was expected.

\section{Study 1}

In the first study two episodes of strong impact on the mass media and the public opinion were analyzed: the death of two relevant politicians. In the first place, Muguruza, -a nationalist parliamentary- was killed in 1989. This action, though not in an explicit way, was self-attributed by G.A.L. In the second place, Múgica, -a non-nationalist politician-, was killed in 1996, an action that was claimed by E.T.A. Both actions received great attention in the mass media.

\section{Method}

The corpus was constituted by the editorials of nationalist and non-nationalist newspapers coming from four newspapers: two nationalist newspapers (Egin and Deia) and two nonnationalists (Diario Vasco and $A B C$ ).

\section{Procedure}

First, all sentences referring to the victim or the aggressor as the sentence subject were coded by two independent judges (Kappa 0.81) into four levels of abstraction (DAV, IAV, SV, ADJ) following the LCM (Semin \& Fiedler, 1991). Then, all sentences referring to the DAV and IAV linguistic categories were recoded into a new concrete category and the SV and ADJ linguistic categories into a new abstract category.

\begin{tabular}{cccccc}
\hline & & \multicolumn{2}{c}{ Linguistic abstraction used in events where (non)nationalist politicians } \\
were killed & & \multicolumn{2}{c}{ Nationalist politician } \\
\hline $\begin{array}{c}\text { Sentence sub- } \\
\text { ject }\end{array}$ & $\begin{array}{c}\text { Ideological view } \\
\text { of newspaper }\end{array}$ & Non-Nationalist politician & Abstract & Concrete & Abstract \\
\hline \multirow{2}{*}{ Aggressor } & Nationalist & $59 \%$ & $41 \%$ & $66 \%$ & $34 \%$ \\
\hline \multirow{2}{*}{ Victim } & Non-Nationalist & $28 \%$ & $72 \%$ & $96 \%$ & $4 \%$ \\
\hline & Nationalist & $51 \%$ & $49 \%$ & $79 \%$ & $20 \%$ \\
\hline
\end{tabular}

Table 1. Percentages of linguistic categories according to the aggressor of nationalist versus non-nationalist politician, victim and newspaper's point of view 


\section{Results}

A 2 (political view of the newspaper: nationalist vs. non-nationalist) $\times 2$ (sentence subject: victim vs. aggressor) $\times 2$ (level of abstraction: concrete vs. abstract) log-linear analysis was performed. Results confirmed the hypothesized tree-way interaction $\left(\mathrm{x}^{2}(1\right.$, $N=920)=26.55, p<0.001)$ (see Table 1).

As far as the aggressor is concerned, in the case of Mugica it was found that more than $2 / 3$ of the sentences of the non-nationalist press were abstract (SV or ADJ) as compared to less than $50 \%$ in the nationalist press. Similarly, in the case of Muguruza it was found that $1 / 3$ of the terms used by the nationalist press were abstract as compared to only $4 \%$ in non-nationalist press. Thus, the nonnationalist press used a higher level of abstraction to describe the aggressor of the nonnationalist politician than to describe the aggressor of the nationalist politician, whereas the nationalist press used a higher level of abstraction to describe the aggressor of the nationalist politician than to describe the aggressor of the non-nationalist politician. This would replicate the LIB effect for negative behaviours performed against ingroup and outgroup members. Perpetrators of ingroup victims are derogated to a greater extent than perpetrators of outgroup victims. However, results do not support expectations regarding differences in the descriptions of perpetrators by nationalist newspapers. Nationalist newspapers used similar abstraction in language to describe aggressors of either ingroup or outgroup victims.

As far as the victims are concerned, no differences in the level of abstraction emerged between nationalist and non-nationalist newspapers. A similar effect was found in other studies (Maas et al., 1994, study 2).

\section{Discussion}

Results of this first study found evidence of the LIB in the area of the mass media, because the newspapers used a higher level of abstraction to describe the aggressor of the ingroup politician than the outgroup politician, as well as a higher level of abstraction to describe the aggressor of the ingroup politician than the outgroup politician. Unexpected results were obtained regarding the similar abstraction level used by the nationalist press to describe perpetrators on both na- tionalist and non-nationalist victims. This effect may be due to the differences in ideology that the readers may hold in the case of nationalist and non-nationalist newspapers. Nationalist newspapers are read by people of nationalist and non-nationalist ideology, mostly in the Basque Country. Non-nationalist newspapers are read mainly by nonnationalist readers. The differences in the ideology held by readers could impose communicative goals in the language used by journalists. Nationalist newspapers journalists have to write to a heterogeneous audience, which imposes control over the language that is used to describe violent events concerning politics. In fact, if this were the case, journalists would likely use a more concrete language, as the results seem to show. Recent literature regarding the LIB suggests that even if the LIB has been said to emerge out of awareness (Von Hippel, Sekaquaptewa, \& Vargas, 1995), the LIB is nonetheless determined by communicative goals, such as the characteristics or nature of the audience (Ruscher \& Duvall, 1998).

Moreover, the fact that we didn't find differences in relation to the description of the victim provides evidence for the possible effects of the "cross-categorisations" to identify the victim in the nationalist versus non-nationalist mass media.

\section{Study 2}

In the second study, language use in the media was analyzed in a critical moment of the Basque political sphere: the ceasefire of ETA. In 1998 ETA declared a truce. This issue received great attention in the media. Indeed, nationalist political parties proceeded to ask for a negotiation leading to the selfdetermination of the Basque Country, while non-nationalist political parties felt negotiation as a threat to the unity of Spain.

\section{Method}

As in study 1 , newspaper editorials were analyzed: two nationalist newspapers (Euskadi Informacion and Deia) and three non-nationalist newspapers (El Diario Vasco, El Mundo and $A B C)^{1}$. It was hypothesised that the language

\footnotetext{
1 Different newspapers were used through the 3 studies due to two problems. On the one hand, we wanted to have right-wing and left-wing or center points of view of nationalist and non-nationalist newspapers. On the other
} 
used by the diverse newspapers would reflect different levels of abstraction in the description of ingroup or outgroup sentence subjects depending on the political position they supported.

\section{Procedure}

Similarly to the first study, concrete and abstract categories were produced (Kappa .80). A careful content analysis of the sentence subjects revealed four main categories: ETA, Nationalists, Non-nationalists and Truce. A 4 (sentence subject: ETA, Nationalists, Nonnationalists, Truce) $\times 2$ (political view of the newspaper: nationalist vs. non-nationalist) $\times 2$ (level of abstraction: concrete vs. abstract) $x$ 2 (valence of the linguistic category: positive vs. negative) design was then used.

\section{Results}

First, regarding descriptive statistics related to the use of the different linguistic categories, it was found that all newspapers used a higher amount of verbs to describe ETA and non-nationalists than to describe nationalists and truce. A quick look of Table 2 reveals that as a whole, negative linguistic categories are systematically described in a more abstract level than positive linguistic categories. This systematic trend has been previously found and labelled as negativity bias in impression formation research. Also, this line of research has found that negative traits give more information about the subject, which explains why negative traits are described in a more abstract way (Fiedler, Semin \& Finkenauer, 1993).

Second, a 2 political view of newspaper (nationalist, non-nationalist) $\times 4$ sentence subject (ETA, nationalists, non-nationalists, truce) $\times 2$

hand, due to the adding of the valence condition to the second and third studies, more sentences were required non-nationalist newspapers used fewer sentences than nationalist newspapers-. In relation to the nationalist newspapers, the left had problems with the law. Egin was closed down in 1998 by the Audiencia Nacional charged on collaboration with ETA. Immediately after, Euskadi Informacion appeared and finally, in 1999, Gara was launched. In relation to the non-nationalist newspapers, the problem was different. In comparison to the first study, the second and third studies needed a valence condition. At the time of the first study, El Mundo did not exist. In order to have center and right-wing points of view, $A B C, E l$ Mundo and Diario Vasco were used in the last two studies and only El Pais was added in the third study. linguistic category valence (positive, negative) $\times 2$ level of abstraction: (concrete, abstract) log-lineal analysis was performed. Results confirmed the hypothesized four-way interaction $\left(x^{2}(4, N=507)=9.49, p<0.05\right)$.

As far as the first sentence subject ETA is concerned, nationalist and non-nationalist newspapers were more likely to use negative terms more abstractly than positive ones $\left(x^{2}(1, N=200)=3.40, p<0.05\right)$. However, the difference between positive and negative terms was more pronounced in non-nationalist newspapers.

As far as the sentence subject nonnationalists is concerned, nationalist newspapers used a higher level of abstraction in the negative descriptions than in the positive descriptions $\left(x^{2}(1, N=128)=3.10, p<0.04\right)$. This pattern of results only emerges in the case of nationalist newspapers. In this way, the negative information about non-nationalists was described in an abstract way, attributing the negative characteristics of the outgroup to stable dispositional aspects of their personality.

In relation to the sentence subject nationalists, nationalist newspapers described their positive actions in a more abstract level than negative ones $\left(x^{2}(1, N=61)=3,75, p<.05\right)$. In contrast, non-nationalist newspapers conveyed nationalists' negative actions more concretely than their positive actions. Table 2 shows that the description pattern emerging from the nationalist and non-nationalist subject sentences are rather opposed. In the case of nationalist newspapers, the positive information about nationalists is praised. In the case of non-nationalist newspapers, when describing nationalists, the positive information is used in a more concrete way, while the negative information is used in a more abs-stract way. This differential use of the abstraction in positive and negative descriptions is aimed at downgrading the outgroup.

Finally, as far as the sentence subject TRUCE is concerned, no different patterns of descriptions appeared $\left(x^{2}(1, N=118)=2.96, p<\right.$ $0.05)$. The two kinds of newspapers used positive descriptions in a more concrete way, and negative ones in a more abstract way. Thus, according to this linguistic pattern, the newspapers' use of concrete positive characteristics of the truce gives room to inferences of 
inconsistency, as if it were driven by the context and as not enduring in the future. In contrast, as they use abstract terms to represent the negative dimensions of the truce, they give room to underlining that the conflict is likely to endure in the future.

\begin{tabular}{|c|c|c|c|c|c|c|c|c|c|}
\hline & & \multicolumn{8}{|c|}{ Sentence subject } \\
\hline & & \multicolumn{2}{|c|}{ ETA } & \multicolumn{2}{|c|}{ Non-Nationalist } & \multicolumn{2}{|c|}{ Nationalist } & \multicolumn{2}{|c|}{ Truce } \\
\hline \multirow{2}{*}{$\begin{array}{c}\text { Political } \\
\text { view of } \\
\text { newspaper }\end{array}$} & \multirow{2}{*}{$\begin{array}{l}\text { Valence of } \\
\text { categories }\end{array}$} & \multicolumn{8}{|c|}{ Abstraction level } \\
\hline & & Conc. & Abs. & Conc. & Abs. & Conc. & Abs. & Conc. & Abs. \\
\hline \multirow{2}{*}{ Nationalist } & Negative & $50 \%$ & $50 \%$ & $48 \%$ & $52 \%$ & $75 \%$ & $25 \%$ & $25 \%$ & $75 \%$ \\
\hline & Positive & $59 \%$ & $41 \%$ & $75 \%$ & $25 \%$ & $53 \%$ & $47 \%$ & $55 \%$ & $45 \%$ \\
\hline \multirow{2}{*}{$\begin{array}{c}\text { Non- } \\
\text { Nationalist }\end{array}$} & Negative & $45 \%$ & $55 \%$ & $59 \%$ & $41 \%$ & $54 \%$ & $56 \%$ & $21 \%$ & $79 \%$ \\
\hline & Positive & $90 \%$ & $10 \%$ & $60 \%$ & $40 \%$ & $82 \%$ & $18 \%$ & $61 \%$ & $39 \%$ \\
\hline
\end{tabular}

Table 2. Percentage of linguistic categories regarding the sentence subject, newspaper's perspective and valence.

Moreover, in order to analyze the role played by the intentional causality dimension in the level of abstraction found in the descriptions, a 2 political view of newspapers (nationalist, non-nationalist) $x 4$ sentence subject (ETA, nationalists, non-nationalists and truce) $\times 2$ valence of the category (positive, negative) $x$ 2 linguistic category (IAV, SV) long-lineal analysis was performed. Results confirmed the hypothesized four-way interaction $\left(X^{2}\right.$ (4) $=182,16 \mathrm{p}<.00)$. The language used by newspapers of different political views also revealed a significant difference $\left(\underline{X}^{2}(1)=\right.$ $104,97 \mathrm{p}<.00)$. Generally, newspapers produced more intentionally driven descriptions (IAV) than context driven descriptions (SV). However, nationalist newspapers, when compared to non-nationalist newspapers, used a higher proportion of positive descriptions at a lower level of causal intentionality (SV). On the one hand, non-nationalist newspapers, when compared to nationalist newspapers, used a higher proportion of negative descriptions at a higher level of causal intentionality (IAV).

\section{Discussion}

The results of the second study suggest that a different abstraction is used in the area of the mass media as a function of the ideological viewpoint of the communicator. As compared to the results of the first study, results show that this different use of abstracion is also employed in a more peaceful context. Indeed, non-nationalist newspapers used the LIB when describing ETA and nationalists. Particularly, positive information about ETA and nationalists was conveyed at a more concrete level of linguistic abstraction while negative information about them was represented at a more abstract level. There is not a clear linguistic pattern however when newspapers describe negative information about nonnationalists. As far as the nationalist newspapers are concerned, the LIB is used when describing ETA, rather similarly to the pattern emerged in the case of non-nationalist newspapers. However, in this case the pattern is softer. When describing non-nationalists, nationalist newspapers do show the LIB pattern, showing the opposite pattern in the case of the description of nationalists.

Moreover, in relation to the intentional causality dimension, it was found that while both kinds of newspapers gave more descriptions underlining a high level of intentional causality, nationalist newspapers used positive descriptions to a greater extent to give room to contextual inferences, while the non-nationalist newspapers are more prone to use the opposite pattern in this dimension.

\section{Study 3}

In the third study, the banning of Euskaldunon Egunkaria (the only newspaper entirely edited in Basque language) was analyzed. In 2003, the Spanish High Court closed down the Euskaldunon Egunkaria newspaper. This event was extensively discussed by mass media and public opinion, and was subject to strong arguments between nationalist and nonnationalist parties in the Basque Country and in Spain. 


\section{Method}

Six newspaper editorials were included. Two of these editorials were nationalist newspapers (Gara and Deia) and four were nonnationalist newspapers (El Diario Vasco, El Mundo, El Pais and $A B C$ ). It was hypothesized that the language used by the different ideological newspaper viewpoints would be furnished by different levels of abstraction in the description of the sentence subject.

\section{Procedure}

First, only sentences that referred to Basque sentence subjects (Basque political parties, Basque Government, politicians, journalists, people, etc.) or to Spanish sentence subjects (High court, Spanish government, Spanish political parties, Spanish judicial system, etc.) were analyzed for the purpose of this study. Then, two independent judges (Kappa .80) selected all sentences referring to the subject, and the level of abstraction was coded (DAV, IAV, SV, ADJ) following the LCM (Semin \& Fiedler 1991). The design used in this study consisted of a 2 (ideological view of the newspaper: nationalist vs. non-nationalist) $\times 2$ (sentence subject: Basque vs. Spanish) $\times 4$ (level of abstraction: DAV, IAV, SV, ADJ) $\times 2$ (valence of the category: positive vs. negative) design.

\section{Results}

First, a 2 (ideological view of the newspaper: nationalist, non-nationalist) $\times 2$ (sentence subject: Basque, Spanish) x 4 (level of abstraction: DAV, IAV, SV, ADJ) $\times 2$ (valence of the category: positive, negative) log-lineal analysis was performed. Results confirmed the hypothesised four-way interaction $\left(\mathrm{x}^{2}(4, N=444)\right.$ $=98.49, p<0.001$ ).

\begin{tabular}{|c|c|c|c|c|c|}
\hline \multicolumn{6}{|c|}{ Sentence subject: Basque } \\
\hline & & \multicolumn{4}{|c|}{ Linguistic category } \\
\hline & & DAV & IAV & SV & ADJ \\
\hline \multirow{2}{*}{ Ideological view of newspaper: Nationalist } & Negative & 36.36 & 54.55 & 9.09 & 0.00 \\
\hline & Positive & 10.53 & 63.16 & 5.26 & 21.05 \\
\hline \multirow{2}{*}{ Ideological view of newspaper: Non-Nationalist } & Negative & 15.27 & 45.04 & 3.82 & 35.88 \\
\hline & Positive & 25.00 & 60.00 & 5.00 & 10.00 \\
\hline \multicolumn{6}{|c|}{ Sentence subject: Spanish } \\
\hline & & \multicolumn{4}{|c|}{ Linguistic category } \\
\hline & & DAV & IAV & SV & ADJ \\
\hline \multirow{2}{*}{ Ideological view of newspaper: Nationalist } & Negative & 35.19 & 27.78 & 0.00 & 37.04 \\
\hline & Positive & 15.38 & 69.23 & 7.69 & 7.69 \\
\hline \multirow[b]{2}{*}{ Ideological view of newspaper: Non-Nationalist } & Negative & 36.84 & 31.58 & 5.26 & 26.32 \\
\hline & Positive & 26.72 & 39.69 & 3.82 & 29.77 \\
\hline
\end{tabular}

Table3. Percentage of linguistic categories regarding the sentence subject, newspaper's and valence.

Nationalist and non-nationalist newspapers reported negative descriptions of their own group targets in more concrete terms (DAV) and fewer in abstract terms (ADJ). Positive descriptions, though, were represented in more abstract terms when performed by ingroup members than when they were performed by outgroup members. This is the classic LIB effect, aiming at gaining a positive identity by locating ingroup behaviours in a positive position, whereas outgroup behaviours are downgraded

When the intentional causality of the language use is examined, results show that when describing their own group, reporters make a more frequent use of negative terms at a SV level than when positive terms are used. In this way, the initiation of the event is attributed to the sentence object, i.e., the outgroup. In contrast, the opposite pattern is revealed when the outgroup is considered as 
the target of the communication. SV are more likely to be used in positive descriptions of outgroup members than for their negative descriptions. Initiation of the positive event regarding the outgroup tends to be attributed to ingroup members. In sum, in relation to the dimension of intentional causality, both types of newspapers used opposite strategies when describing the ingroup and the outgroup.

\section{Discussion}

In general terms, results indicate that media bias -considered in terms of the ideological viewpoint of a newspaper- influences the level of abstraction of the language used to describe the banning of a newspaper.

On the one hand, ideological bias is reflected in the fact that nationalist newspapers describe negative events led by Basque groups and Basque institutions by using a more concrete linguistic level, and positive descriptions by using a higher level of abstraction. Besides, partiality is also revealed when nonnationalist newspapers describe Basque groups and Basque institutions by using positive descriptions at a more concrete level and negative descriptions at a more abstract level. Newspapers ideological partiality is also reflected in the descriptions of ideologically driven objectives. The bias reflected in the use of linguistic abstraction provides evidence that support the relevant role of the dimension of dispositionality in the use of language: it detaches the actor from the context or it fixes the actor to the context in order to foster inferences about the dispositional features as the cause of the event to the addressee of the communication.

On the other hand, results also showed that when reporters support the nationalist point of view in the conflict, they describe negative events led by Basque groups and institutions using more SV, and positive events using more IAV. On the contrary, reporters supporting a non-nationalist point of view in the conflict describe positive actions of Basque groups and institutions using more IAV and negative actions by using more SV. The opposite pattern appears when Spanish groups or institutions are described. This bias is represented in the different events by using more IAVs or SVs. that provide support for the relevant role the dimension of causal intentionality plays on the use of language. Using language this way induces inferences about the controllability of the behaviour, leading to denial of responsibility regarding the actor in the case of SV and to addressing responsibility to the actor in the case of the use of IAV.

\section{General discussion}

The results of the three studies described shed light on the analysis of normative pragmatic regulations of the language used in the area of mass communication in order to induce subtle inferences about the causes of the event. There are several features of the language used in the media that differentiates it from the traditional laboratory analysis (Semin et al., 1989). First, the rate of abstract language (i.e. ADJ) is much lower than in comparable laboratory studies and, in general, the discourse is restricted to a more frequent use of concrete terms in the three studies, indicating the concrete verifiable information in the media. This more frequent use of concrete terms varies as a function of who or what is described: aggressor compared to the victim in the first study, ETA's violent actions compared to the cease fire in the second one, and the banning of a newspaper compared to two prior political events in the third one. Second, supporting one of the two most distinct poles in the Basque conflict leads reporters to use abstract terms more frequently, showing less verifiable information in the media.

The first study provides evidence for the use of the LIB in the mass media. On the one hand, it was found that the non-nationalist press used more abstract categories than the nationalist press regarding the aggressor of the nonnationalist politician, whereas the nationalist press used more abstract categories than the non-nationalist press regarding the aggressor of the nationalist politician. However, the possible "cross-categorisations" of the victim, with regard to the victim's descriptions, as well as in the study of Maass et al., (1994), may explain the lack of significant differences in the use of language. Moreover, when comparing the proportions of abstract categories used by the nationalist press in relation to nationalist politicians and the proportions of the non-nationalist press in relation to non-nationalist politicians, to the proportions of the study of Maass et al., (1994) it can be said that the rate of abstraction of our sample is generally higher (non- 
nationalist press to the aggressor of the nonnationalist politician $=71 \%$; nationalist press to the aggressor of the nationalist politician $=35$ $\%$, while Jewish press to the aggressor of the Jewish editor $=25 \%$ ). These results would also provide evidence for the role the context of political conflict plays in the functioning of the LIB.

The second and third studies found evidence again to support the biased use of linguistic abstraction in the area of mass media. On the one hand, compared to findings of the first study, results from the second study show that this different use of linguistic abstraction is also likely to occur in a more peaceful context. On the other hand, the second and third studies indicate that the dimension of dispositionality is qualified by the desirability of the descriptions. In other words, the position the reporters hold on the political conflict influences the use of linguistic abstraction. Nonnationalist newspapers' use of positive information about ETA and nationalists (Study 2) and about the outgroup (Study 3 ) is conveyed at a concrete level, while negative information about them is displayed at an abstract level. As far as the nationalist newspapers are concerned, the same pattern is displayed in relation to ingroup and outgroup targets.

Finally, in relation to the intentional causality dimension, it was found that while both kinds of newspapers used more IAV in their descriptions (Study 2), linguistic intentionality was not as used in the case of the banning a newspaper (Study 3). Moreover, while results of the second study revealed that nationalist newspapers used more positive descriptions of low intentionality (SV) than negative ones, the third study suggested that this general trend was more commonly used to describe outgroup behaviours. This helped reporters give room to more contextual inferences. The nonnationalist newspapers used the opposite pattern. In general terms, the study shows consistent evidence so as to convey a more dispositional and intentional language in the description of the adversary. Concretely, positioning for or against the political conflict leads, in a subtle way, to the pragmatic use of language, providing the public sphere with a meaning of higher dispositionality and lower intentional causality for ingroup targets, and lower dispositionality and higher intentional causality for outgroup members.
Is this bias an individual bias as the more cognitivist researchers posit, or is it a kind of pragmatic speech act that has to do more with the triadic vision (Moscovici, 1986) with a more dialogical version (Markova, 2000) or with the discursive version (Van Dijk, 1990; 1998) of social behaviour? This mysterious effect might have two possible explanations. First, the effect could be due to a very well learned automatic mechanism -with a cognitive individual basis- that involves the expression of stereotyped beliefs and meanings (i.e., Franco \& Maass, 1996; Von Hippel et al., 1995) regardless of the presence of a listener or an audience. A second explanation is in our view more reasonable. The framing for or against the political conflict on the newspapers behalf is reflected in the use of different normative logics when expressing descriptions about events. Specifically, results might be interpreted in terms of different pragmatic patterns. Results of linguistic abstraction might possibly derive not only from a bias in the sense of social cognition, but also from a) an audience that is assumed to consume news, and more importantly, b) a specific audience to whom the message is directed.

The biased linguistic patterns might not be entirely due to a 'cognitive bias', as social cognition research posits, but may also be explained as the result of the pragmatic requirement of the speech act. This pragmatic requirement might be determined by an implicitly assumed audience, that is, a public sphere that plays the role of an audience (Chiu, Krauss \& Lau, 1998). It is also determined by the intention to address in the speech act an adversarial audience in a context where a triadic relationship emerges among the source of a message, the addressee and the social object of reference: the public sphere (see also Semin,Gil de Montes, \& Valencia, 2003; Gil de Montes, Semin \& Valencia, 2003). Although the issue is seldom addressed directly, this pragmatic regulation requires a kind of perspective-taking which is implicit in the approach proposed here (See also Tversky \& Kahneman 1991; Grice 1975). For example, the Gricean Maxim of Quantity instructs speakers to make their contributions as informative as is required for the purposes of the exchange, but to be sure their contributions are not more informative than is required. However, the informativeness of a message can be specified only with regard to 
a particular addressee; a message that is inadequately informative for an addressee might be more informative than it is required for a different addressee. To formulate messages that conform to the Maxim of Quantity, a speaker has to assess the addressee's knowledge. Wilks \& Balin (1987) makes a similar point with respect to the Maxim of Quality.

In sum, the studies presented here suggest that the use of different levels of abstraction in the language used by the mass media can be understood like speech acts, i.e., the production of expressions, meanings and actions ideologically immersed in social relations (Van Dijk, 1998), that play the role of preserving groups' identity in conflicts, where social representations act as self-service and the preservation of symbolic interests of adversarial positioning. From a slightly different theoretical view, Van Dijk (1998) differentiates between shared systems of social representations based on the shared social knowledge and situational or pragmatic models based on the personal experiences and interpretations. It is by means of the interface between the normative pragmatic logics and the positioning of perspectives that the pragmatic use of language in the media can be explained.

More research, however, is needed in order to understand the relation between pragmatic use of language and social representations. In Moscovici's words: A closer examination of our past ideas and recent
evolutions leads me to think that the time has
come to reconsider some options. Yes, the time
has come to loosen the link with semantic com-
munication, which is too exclusive, and take
more interest in pragmatic communication. I am
not saying that the former must be given up in
favour of the latter, which would be meaningless,
but simply that since representations are fash-
ioned and shared at these two levels of content,
one would do well to take both into account
(1994, p. 165).

\section{References}

Beauvois, Jean-Léon; Gilibert, Daniel; Pansu, Pascal \& Abdelaoui, Sid (1998). Internality, attribution and intergroup relations. European Journal of Social Psychology,28(2), 123-141.

Brown, Roger \& Fish, Deborah (1983). The psychological causality implicit in language. Cognition, 14, 237-273.
Cates. Karen \& Messick. David (1996). Prequentistic adverbs as measures of egocentric biases. European Journal of Social Psychology,26(1), 155161.

Chiu, Chi-yue; Krauss, Robert M. \& Lau, Ivy C-M. (1998). Some cognitive consequences of communication. In Susan Fussell \& Roger J. Kreuz (Eds.), Social and cognitive approaches to interpersonal communication (pp. 259-276). Mahwah. NJ. USA: Lawrence Erlbaum Associates. Inc.

De Mateo, Rosario (1989). The Evolution of the Newspaper Industry in Spain, 1939-1987. European Journal of Communication, 4, 211-26

Doise, Willem (1990). Les représentations sociales. In Rodolphe Ghiglione, Claude Bonnet \& JeanFrançois Richard (Eds.), Traité de Psychologie Cognitive (pp. 111-174). Paris: Dunod.

Doise, Willem (1993). Logiques Sociales dans le Raisonnement. Neuchatel: Delachaux \& Niestle.

Doise, Willem \& Staerklé, Christian (2001). From social to political psychology: The societal Approach. In Kristen Monroe (Ed.), Political Psychology (pp. 151-72). Nex York: Erlbaum.

Fiedler, Klaus; Bluemke, Matthias; Friese, Malte \& Hofmann, Wilhelm (2003). On the different uses of linguistic abstractness: from LIB to LEB and beyond. European Journal of Social Psychology, 33, 441-453.

Fiedler, Klaus; Semin, Gün R. \& Finkenauer, Catrin (1993). The battle of words between gender groups: A language-based approach to intergroup processes. Human Communication Research, 19(3), 409-441.

Flament, Claude (1999). La représentation sociale comme systéme normatif. Psychologie et Societé, 1, 29-54.

Franco, Francesca \& Maass, Anne (1996). Implicit vs.. Explicit strategies of outgroup discrimination: The role of intentional control in biased language use and reward allocation. Journal of Language and Social Psychology, 15(3), 335-359.

Gil de Montes, Lorena; Semin, Gün R. \& Valencia José F. (2003). Communication patterns in interdependent relationships. Journal of Language and Social Psychology, 22(3), 3259-3281.

Grice, H. Paul (1975). Logic and conversation. In Peter Cole \& Jerry Morgan (Eds.), Syntax and semantics: Vol. 3, Speech acts (pp. 41-58). New York: Academic Press.

Grize, Jean-Blaise (1989). Logique naturelle et representations sociales. In Denise Jodelet (Ed.), Les representations sociales (pp. 152-68). Paris: PUF. 
Ichheiser, Gustav (1949). Misunderstandings in human relations: a study in false social perception. American Journal of Sociology, 55(2), 1-72.

Jellison, Jerald M. \& Green, Jane (1981). A selfpresentation approach to fundamental attribution error: the norm of internality. Journal of personality and social psychology,40(4), 643-649

Kelley. Harold (1973). The process of causal attribution. American Psychologist, 28, 107-128.

Krauss, Robert \& Chiu, Chi-Yue (1998). Language and social behavior. In Daniel Gilbert, Susan Fiske \& Gardner Lindzey (Eds.), Handbook of social psychology, vol. 2 (pp. 40-88). New York: McGraw-Hill.

Maass, Anne (1999). Linguistic intergroup bias: stereotype perpetuation through language. In Mark P. Zanna (Ed.), Advances in Experimental Social Psychology, vol. 31 (pp. 79-122). San Diego: Academic Press.

Maass, Anne \& Arcuri, Luciano (1992). The role of language in the persistence of stereotypes. In Gün R. Semin \& Klauss Fiedler (Eds.), Language, interaction and social cognition (pp. 129-143). Newbury Park: Sage.

Maass, Anne; Corvino, P. \& Arcuri, Luciano (1994). Linguistic intergroup bias and the mass media. Revue de Psychologie Sociale, 1, 31-43.

Maass, Anne; Salvi, Daniela; Arcuri, Luciano \& Semin, Gün R. (1989). Language use in intergroup contexts: The linguistic intergroup bias. Journal of Personality and Social Psychology, 57, 981-993

Markov, Ivana (2000). Ameédée or how to get rid of it: social representations from a dialogical perspective. Culture and psychology,6(4), 419460.

Moscovici, Serge (1976). La psichanalyze, son image et son publique. Paris: PUF.

Moscovici, Serge (1986). L'ére des représentations sociales. In Willem Doise \& Augusto Palmonari. (Eds.), L'etude des representations sociales (pp. 34-80). Neuchatel: Delachaux et Niestlé

Moscovici, Serge (1994). Social representations and pragmatic communication. Social Science Information, 33, 163-177.

Rudolph, Udo \& Forsteling, Friedrich (1997). The psychological causality implicit in verbs: A review. Psychological Bulletin,121(2), 192-218.

Ruscher, Janet B. \& Duval, Laura Lawson (1998). Multiple communicators with unique target information transmit less stereotypical impressions. Journal of Personality and Social Psychology, 74 (2), 329-344.
Schmid, Jeannette \& Fiedler, Klauss (1998). The backbone of closing speeches: The impact of prosecution versus defense language on judicial attributions. Journal of Applied Social Psychology, 28, 1140-1172.

Schmid, Jeannette, Fiedler, Klauss, Englich, B., Ehrenberg, Thorsten \& Semin, Gün R. (1996). Taking sides with the defendant: Grammatical choice and the influence of implicit attributions in prosecution and defense speeches, International Journal of Psycholinguistics,12(2), 127148.

Schudson, Michael (2002). The news media as political institutions. Annual Review of Political Science, 5, 249-269.

Semin, Gün R. (1998). Cognition, Language and Communication. In Susan Fussell \& Roger J. Kreuz (Eds.), Social and cognitive approaches to interpersonal communication (pp. 229-257). NJ: Lea. 229-257.

Semin, Gün R. (2000). Agenda 2000: Communication: Language as an implementational device for cognition. European Journal of Social Psychology, 30(5), 595-612

Semin, Gün R. \& Fiedler, Klauss (1988). The cognitive functions of linguistic categories in describing persons: social cognition and language. Journal of Personality and Social Psychology, 54, 558-568.

Semin, Gün R. \& Fiedler, Klauss (1989). Relocating attributional phenomena within a languagecognition interface: the case of actors' and observers' perspectives. European Journal of Social Psychology, 19, 491-508.

Semin, Gün R. \& Fiedler, Klauss (1991). The linguistic category model, its bases, applications and range. In Woldgang Stroebe \& Miles Hewstone (Eds.), European Review of social psychology vol. 2 (pp. 1-50). Chichester: John Wiley.

Semin, Gün R. \& Fiedler, Klauss (1992). Language, interaction and social cognition. London: Sage.

Semin, Gün R.; Gil de Montes, Lorena; \& Valencia, José F. (2003). Communication constraints on the linguistic intergroup bias. Journal of Experimental Social Psychology, 39(2), 142-148.

Semin, Gün R. \& Marsman, J. Gooitske (1994). On the multiple inference-inviting properties of interpersonal verbs: Event instigation, dispositional inferences and implicit causality. Journal of Personality and Social Psychology,67(5), 836849.

Tversky, Amos \& Kahneman, Daniel (1991). Loos aversion riskless choice: A reference-dependent model. Quarterly Journal of Economics. 106(4), 1039-1061. 
Valencia, José F.; Gil de Montes, Lorena, \& Ortiz, Garbiñe (2007). Utilización del lenguaje en contextos políticos y judiciales: Representaciones sociales y la pragmática del lenguaje en acción. In Javier Cerrato \& Augusto Palmonari (Eds.), Representaciones sociales y Psicología social (pp. 205-227). Valencia: Promolibro.

Van Dijk, Teun A. (1990). Social cognition and discourse. In Howard Giles \& Peter Robinson (Eds.), Handbook of language and social psychology (pp. 163-186). New York: John Wiley \& Sons ltd.

Van Dijk, Teun A. (1998). Ideology. Canbridge: CUP.

Von Hippel, William; Sekaquaptewa, Denise \& Vargas, Patrick (1995). On the role of encoding processes in stereotype maintenance. In Mark P. Zanna (Ed.), Advances in experimental social psychology (Vol. 27, pp. 177-254). San Diego: Academic Press.
Wagner, Wolfgang; Kronberger, Nicole \& Seifert Franz (2002). Collective symbolic coping with new technology. British Journal of Social Psychology, 41, 323-343.

Weiner, Bernard (1986). An attributional theory of motivation and emotion. New York: SpringerVerlag.

Wigboldus, Daniël H. J., Semin, Gün R. \& Spears, Russell (2000). How do we communicate stereotypes? Linguistic bases and inferential consequences. Journal of Personality and Social Psychology, 78(1), 5-18.

Wilks, Yorick \& Balin, Afzal (1987, August). Multiple agents and the heuristic ascription of belief. Communication presented at Proceedings of the 10th International Joint Conference on Artificial Intelligence(IJCAI-87), 119-124, Milan, Italy.

Zaller John R. (1998). Monica Lewinsky's contribution to political science. Political Science \& Politics, 31,182-89

\section{JoSÉ FRANCISCO VALENCIA}

Is doctor in psychology and professor of social psychology at the University of the Basque Country.

\section{LORENA GIL DE MONTES}

Is doctor in psychology and titular professor of language and social psychology at the University of the Basque Country.

\section{GARBIÑE ORTIZ}

Is doctor in psychology and Lecturer of psychosocial intervention at the University of the Basque Country.

\section{MAIDER LARRAÑAGA}

Is doctor of psychology and senior lecturer of group psychology at the University of the Basque Country.

\section{AGRADECIMIENTOS}

The research reported in this article was supported by a Research Project from the MEC (SEJ2007$67193 / \mathrm{PSIC}$ ). Also the authors would like to thank the comments by the two reviewers to the previous version of the paper.

\section{DIRECCIÓN DE CONTACTO \\ josefrancisco.valencia@ehu.es}


Jose Francisco Valencia Garate. Dpto. de psicología social y metodología de las ciencias del comportamiento. Avda. de Tolosa, 70(20080) San Sebastián, Spain

\section{FORMATO DE CITACIÓN}

Valencia, José Francisco; Gil de Montes, Lorena; Ortiz, Garbiñe \& Larrañaga, Maider (2011).Normative regulations and the use of language in describing political events: an analysis of the pragmatic use of language on newspapers. Quaderns de Psicologia, 13(2), 19-33. Extraido el [día] de [mes] del [año], de http://www.quadernsdepsicologia.cat/article/view/867

\section{HISTORIA EDITORIAL}

Recibido: 14/01/2011

$1^{\text {a }}$ revisión $17 / 07 / 2011$

Aceptado 26/05/2011 